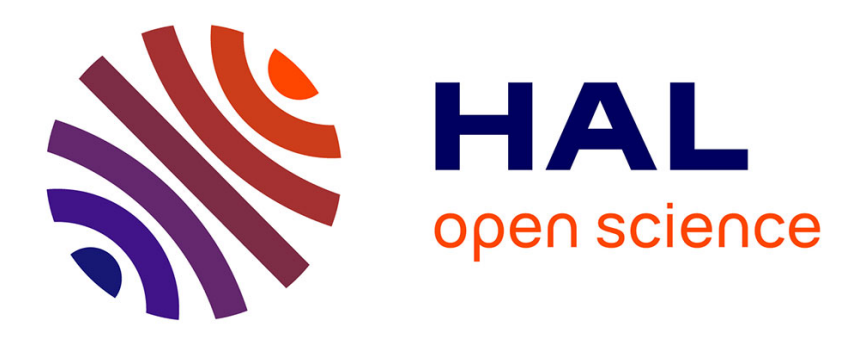

\title{
The predicament of heroic anthropology
}

Albert Doja

\section{To cite this version:}

Albert Doja. The predicament of heroic anthropology. Anthropology Today, 2006, 22 (3), pp.18-22. 10.1111/j.1467-8322.2006.00439.x . halshs-00405952

\section{HAL Id: halshs-00405952 \\ https://shs.hal.science/halshs-00405952}

Submitted on 5 Oct 2009

HAL is a multi-disciplinary open access archive for the deposit and dissemination of scientific research documents, whether they are published or not. The documents may come from teaching and research institutions in France or abroad, or from public or private research centers.
L'archive ouverte pluridisciplinaire HAL, est destinée au dépôt et à la diffusion de documents scientifiques de niveau recherche, publiés ou non, émanant des établissements d'enseignement et de recherche français ou étrangers, des laboratoires publics ou privés. 


\section{The predicament of heroic anthropology}

\section{ALBERT DOJA}

Albert Doja completed his doctoral and postdoctoral research at the École des Hautes Études en Sciences Sociales in Paris and University of Paris-5. Sorbonne. He has lectured and researched in Albania France, England and Ireland. His latest book, Naître et grandir chez les Albanais: La construction culturelle de la personne (Paris:

Harmattan), was published in 2000. He is Senior Research Fellow at the College of Humanities, University of Limerick, Ireland, and Honorary Research Fellow at the Department of Anthropology, University College London.
Fig. 1. The young LéviStrauss as fieldworker and adventurer.

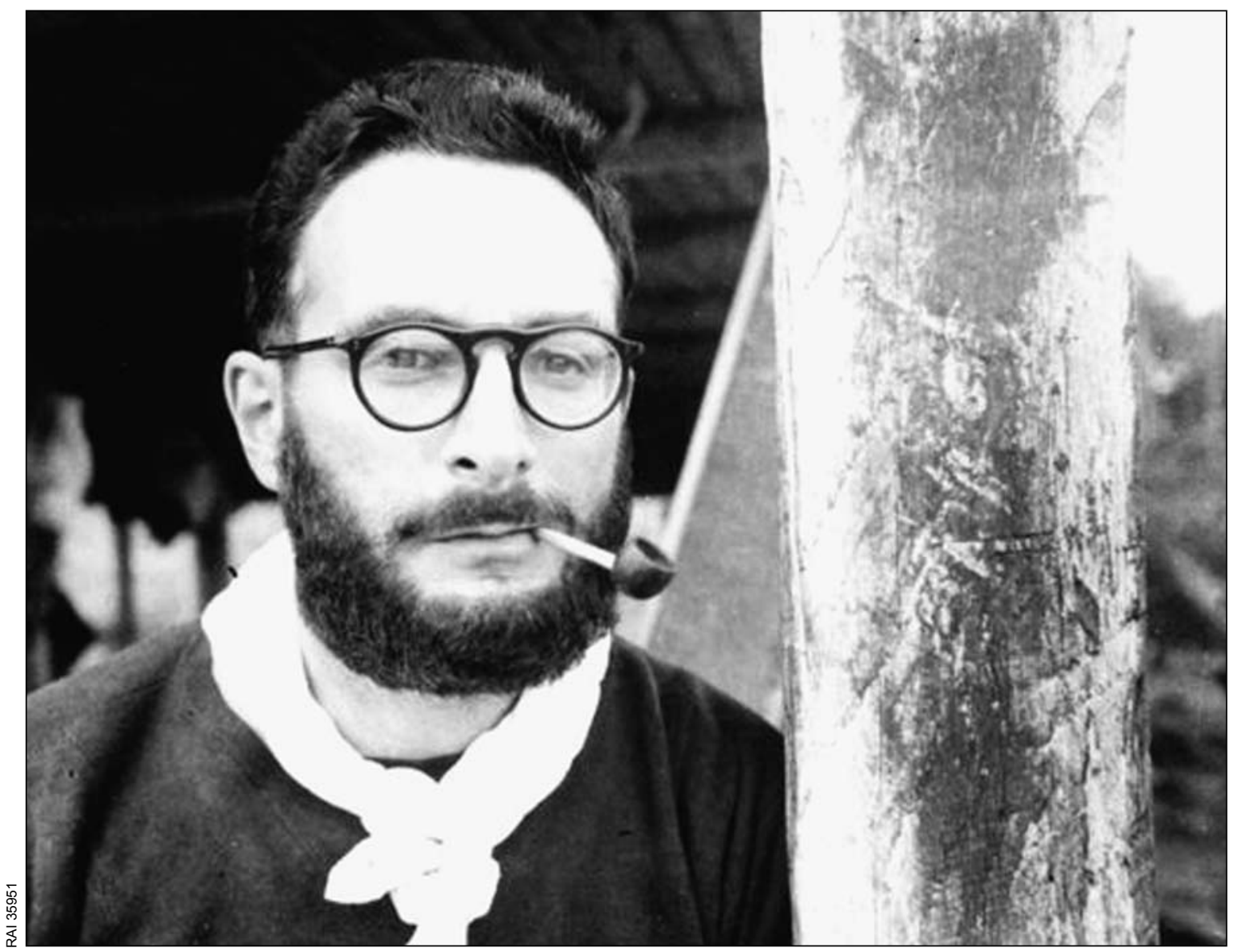

In the course of establishing structural anthropology as an academic discipline in France, Claude Lévi-Strauss has been criticized both on the grounds of anti-humanism (Sartre 1960, Ricoeur 1969) and of its apparent opposite, in the form of a humanistic metaphysics (Derrida 1967a, 1967b). These critics claim to reveal the weakness and alleged contradictions in the work of Lévi-Strauss; he has been accused variously of failure to subject his material to analysis, of ethnocentrism, subjectivism, empiricism, clichéd thinking, archaism, primitivist utopianism, epigenetism, sloppy thinking, nonsense, theology and metaphysics - in short, of everything that is at odds with what normally stands as Lévi-Straussian analysis. I showed elsewhere the critical extent to which Lévi-Strauss's legacy has been misrepresented to the collective detriment of anthropology and social sciences in general (Doja 2005, 2006a). Now if we are to understand the modern condition at all we need to return to Lévi-Strauss' critique of history and colonialism, for his writings helped to make possible modernist ideas of deconstruction, reflexivity, and the transient nature of culture and identity.

\section{The rules of the game}

It is of course not surprising that we find, in various aspects of the new epistemological paradigm of anthropology, the echo of Sartre's reflections on the importance of the interaction between social praxis, human agency and history in understanding symbolic systems (Delacampagne \& Traimond 1997). But although some of the configurations described by Sartre 50 years ago are echoed in the very close attention paid to the details of indigenous discourses by contemporary anthropologists in their accounts of the forms of resistance to oppression, it can be argued - albeit on the basis of completely different materials - that contrary to the beliefs of the majority of post-structuralist critics, Lévi-Strauss is again, if not at the centre, at least very close to the current anthropological paradigm - in any case much closer than Sartre.

Similarly, a synopsis of Lévi-Strauss' critique of Western humanism, which is philosophically expressed in the conception of man as a subject, shows a number of parallels with the principal axes of Heidegger's criticism of modernity (Renaut 1992), a favourite theme of the deconstructionists in other respects (Derrida 1987). It is therefore striking to note how Derrida and his supporters, while criticizing Lévi-Strauss' alleged metaphysical humanism, failed to grasp the philosophical relevance of his struccient for Derrida and his followers simply to borrow from Heidegger the deconstruction of the history of modernity, both its cultural component, with the advent of humanism, and its philosophical aspect, with the advent of philosophies of the subject.

Derrida's Grammatology (1967a) represented an important attack on the foundations of the structural approach, and his technique of 'deconstruction', the best-known or most infamous of post-modernist strategies, has been widely used to destabilize anthropological and other assumptions about language, writing and meaning. Derrida's strategy of critical analysis serves to expose underlying metaphysical assumptions, in particular those which appear to contradict the surface argument of the text itself. The term has tural arguments on this point. It would have been suffi- 
Fig. 2. Claude Lévi-Strauss office in Paris.

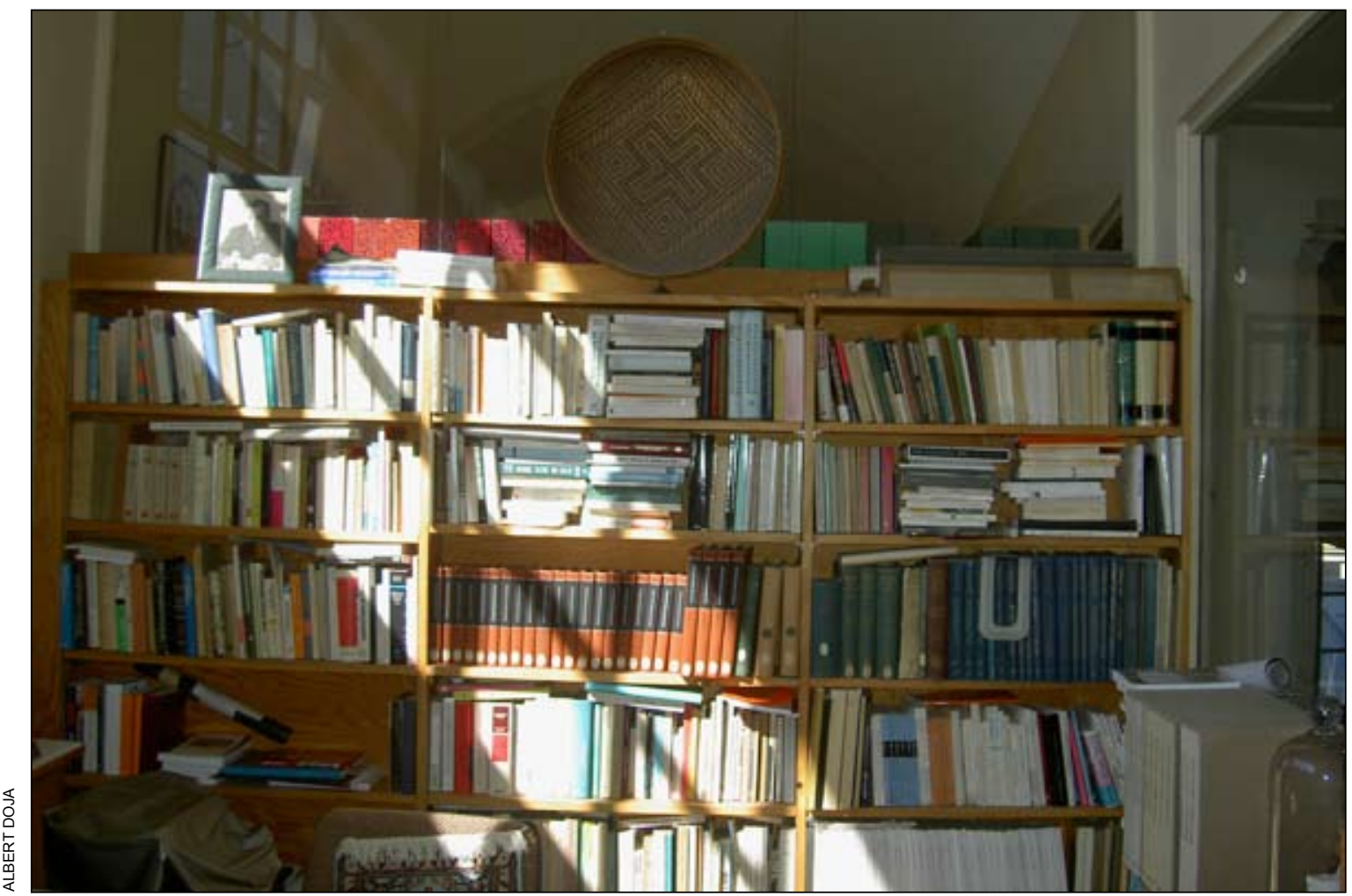

become synonymous with post-modern theory of various sorts, but anthropology has been viewed as an arena particularly appropriate to the post-modernist agenda, especially with regard to unpacking of some of its key terms and concepts such as 'otherness' and 'culture'.

Yet the 'tristes tropes' of post-modernists have identified a genuine and widely acknowledged problem in empiricism and historicism, mainly through their dismissive attitude toward scientific analysis and the largely uncritical appropriation of literary criticism (Polier \& Roseberry 1989). It is hardly surprising, therefore, that Derrida's theories have taken hold especially in North American departments of literature (Haverkamp 1995), while Lévi-Strauss' contribution goes unrecognized, particularly in contemporary North American anthropology.

No wonder, then, that Lévi-Strauss' contribution to the deconstructionist paradigm itself, notably in relation to the wider projects engaged in The savage mind and Totemism, is ignored and largely overshadowed by explicitly literary and philosophical debates (e.g. Lyotard 1979). The post-modern critique, rather than building on it, at best neglected and at worst failed to understand, and therefore rejected, Lévi-Strauss' claim that 'the ultimate goal of the human sciences is not to constitute, but to dissolve man' (1962: 326[247]). Above all, the 'rationality' argument is rarely invoked, despite the fact that it could lay strong claim to having mapped the philosophical parameters of an increasing preoccupation with issues of contextualization and reflexivity within anthropology, in the face of the declining coherence of meta-narrative and grand theory.

\section{A gamble of rhetoric}

Derrida engaged in a very tight game with Lévi-Strauss' work. But using structural anthropology for the purpose of deconstruction meant that the instruments of this deconstruction largely themselves resulted, as Derrida had to recognize, from the structural 'adventure' itself, whether it was 'the sign of an epoch, the fashion of a season or the symptom of a crisis' (Derrida 1967b: 9[3]). After all, to use against an entire movement of thought a critical logic which is incontestably at the basis of that movement is somewhat problematic. Derrida obsessively pursued his programme 'of explicitly and systematically posing the problem of the resources necessary for the deconstruction of that heritage itself' (ibid.: 414[282]). In his desire to deconstruct metaphysics, he was constructing a scholastics.

Derrida's critical engagement with Lévi-Strauss should be seen as a necessary and important intervention in the debate which developed around structuralism in the particular circumstances of 1960s France. Both Derrida and Lévi-Strauss, in their own ways, were responsible for a redefinition of their discipline and for the development of a new 'paradigm'. Whereas in anthropology Lévi-Strauss applied the structural method to the study of social facts, Derrida undertook a radical criticism aiming at the 'deconstruction' of Western philosophical tradition.

However, if Lévi-Strauss' text is for Derrida symptomatic of a specific history of Western metaphysical thought, the urgency of his critique stems from the hegemony of structural discourse, which, he maintains, overstates its claim 'precipitately to have gone beyond' the oppositions of the old metaphysics (Derrida 1967a: 148[99]). Indeed, beyond the question of structuralism and the accusation that it is 'caught, by an entire layer, sometimes the most fecund, of its stratification within the metaphysics of logocentrism', Derrida's intervention can be seen as the clear reaction of philosophy to the challenge of structuralism and the human sciences. It is primarily about a philosophy which is getting the measure of the new anthropology in full flow. In this sense Lévi-Strauss was representative of what was becoming a threat, to the extent of establishing a new arena of intellectual power in the French academy.

Apart from his radical questioning of the history of philosophy and the sciences, Derrida sought to distance himself from the 'controversy' between Sartre and LéviStrauss, revealing the extent to which the debate between anthropology and existentialism seemed obsolete and outdated, a minor skirmish over a boundary which had already shifted. Whereas Sartre's criticism of structuralism, its neglect of concrete relations and its reduction of human agency and historical process, remained squarely within a certain humanistic philosophical tradition, Derrida could be said to have engaged structuralism on its own ground, at the level of its discourse and its concepts. status of a discourse which borrows from a heritage the 
It is clear that what Derrida was charging the new discipline of anthropology with, as it was presented by and represented in the person of Lévi-Strauss, was a lack of discipline at the conceptual level. As I have argued elsewhere (Doja 2006b), Derrida's deconstruction of LéviStrauss' theory of writing aimed to reveal a 'surprising' lack of rigour in a discourse which asserted the scientific credentials of its own concepts whilst claiming to have left behind the categories and abstractions of traditional philosophical discourse.

Nevertheless, structural anthropology was rapidly emerging as one of the strongest decentring forces, especially as it appeared on the intellectual scene 'at the moment when European culture has been dislocated, driven from its locus, and forced to stop considering itself as the culture of reference' (Derrida 1967b: 414 [282]). At about the same time, Foucault (1966) was also highlighting the critical impact of structural anthropology, which was apparent in the particular relationship that the Western rationalism maintained with the societies viewed as primitive. For Derrida, in particular, until the 'event' that inaugurated the structural approach, 'structure, or rather the structurality of structure, although it has always been at work, has always been neutralized or reduced, and this by a process of giving it a centre or of referring it to a point of presence, a fixed origin'. The function of this centre was 'to make sure that the organizing principle of the structure would limit what we might call the play of the structure'. The centre 'is the point at which the substitution of contents, elements, or terms is no longer possible; at the centre, the permutation or the transformation of elements is forbidden' (Derrida 1967b: 409-410 [278-279]).

It is therefore no surprise that Derrida proceeded to analyse in detail the decentring process at work in the LéviStrauss's Mythologiques cycle, where 'there is no unity or absolute source of the myth' (ibid.: 419 [286]). The denial of referential privilege to the Bororo myth chosen by LéviStrauss as the key myth for his analysis, the 'anaclastic' character of myths whose focus and source are 'always shadows and virtualities which are elusive, unactualizable, and nonexistent in the first place' (ibid.: 419 [286]), illustrate the extent to which the challenge of escaping the order of centre, of subject or of author, made Lévi-Strauss one of the key players in the post-modern 'era of suspicion' from the start.

The structural approach in fact posited the concept as indissociable from its representation, and hence the principle that the contents of thought are always subject to being transformed into signifiers, since signs and representations, in their acquired significance, are already interchangeable, capable of standing in successive relations to other entities. As in myths, the 'signified changes into the signifying and vice versa' (Lévi-Strauss 1962: 31 [21]).

In fact, Lévi-Strauss' analysis of mythic activity was symptomatic of this search for a new status of discourse, which was crucial to Derrida and was made possible by ethnographic distance, a discourse relieved 'of all reference to a centre, to a subject, to a privileged reference, to an origin, or to an absolute archia' (Derrida 1967b: 419 [286]). If Derrida is correct that 'there was no centre, that the centre could not be thought in the form of a presentbeing, that the centre had no natural site, that it was not a fixed locus but a function, a sort of non-locus in which an infinite number of sign-substitutions came into play (ibid.: 411 [280]), then he must also agree that the structural approach would reveal the absence of any centre or origin. For the structural approach actually announced what Derrida had in mind when he spoke of 'the moment when, in the absence of a centre or origin, everything became discourse, that is to say, a system in which the central signified, the original or transcendental signified, is never absolutely present outside a system of differences' (ibid.: 411 [280]).

Derrida himself located his own work in the perspective of the rejection of any origin or identity in favour of what it is that makes possible the set of differences by which any concept proves to be interdependent with its own other facets. Paradoxically, at first sight Derrida's grammatological project here meets the eternal question of decentring thought, which was at the very foundation of the moral inspiration which animated both Lévi-Strauss and Rousseau. Indeed, this decentring, like the compassion of Rousseau's natural man, is morally and epistemologically central to Lévi-Strauss (Luhrmann 1990).

Derrida's problematization of the structure of 'writing' reminds us again that what violently differentiates, by generating the differences that are constitutive of complex systems, is a process, a movement, which institutes difference while at the same time holding it in reserve, deferring its presentation or operation. Clearly, all Derrida's 'play of the world' cannot fail, in the last analysis, to come up with the theoretical issue of games and rules, the unconscious constraints that Lévi-Strauss postulated at the foundations of the virtual human mind.

For Derrida, play seems to some extent to be the last word, the last concept that can approach what no word, no concept, no major statement can summarize and command, namely the 'textual movement and spacing out of differences'. Play is made possible by the lack of centre, the absence of foundation. It is thus simultaneously determined by the sign which replaces the centre, a substitute for it added in supplement.

In this respect, when Lévi-Strauss, in his determination to grasp the infinite richness of myth, substitutes the idea of closure for that of the end (1964), his thought can be related to an authentic logic of play, as Derrida himself understood it. According to Lévi-Strauss, the field of myth is 'interminable' but closed upon itself. Indeed, Derrida's claim reveals no more than what Lévi-Strauss had already discovered in myth. For the field of play 'allows infinite substitutions only because it is finite, because instead of being inexhaustible, instead of being too large, there is something missing from it, a centre which arrests and grounds the play of substitutions' (Derrida 1967b: 423 [289]).

The radical experience of both Derrida's philosophy and Lévi-Strauss' anthropology centres on the discovery of that 'structure of substitution such that any presence will be the supplement substituted for the absent origin'. A superabundance of signifier corresponds to this absence of the central signified: that is, in Lévi-Strauss' terminology with which Derrida (1967b: 424 [289-290]) complies, the addition of a 'floating signifier'. Moreover, Derrida acknowledged the importance of the concept of play in Lévi-Strauss and his frequent references to all sorts of games, notably roulette, insisting that 'the so frequent metaphor of the player in Lévi-Strauss' texts must be studied' (ibid.: 425 [290]). He could then acknowledge structural anthropology as the exemplary moment in which 'the historical concatenation is thought under the concepts of play and chance' and discontinuity (1967a:195 [134]), by the same token making 'the philosophical or epistemological requirement of a centre appear as mythological, that is to say, as a historical illusion' (1967b: 421 [287]). Clearly, the way Lévi-Strauss leads up to the theoretical issue of play has a topicality and modernity to which Derrida's project of grammatology itself lays claim, that is, a general understanding of the plurivocality of writing, in its philosophical and semiological implications.

Given the clarity with which both Lévi-Strauss and Derrida come to 'dissolve' and 'deconstruct' the philosophical system and 'man' as its privileged subject, their 
respective approaches would appear to be demonstrably complementary. Such is not Derrida's opinion, however. Just at the point when he was tending towards recognizing a similarity of perspectives between his own work and Lévi-Strauss' approach, Derrida stopped short. Parochially restricting himself, he stubbornly refused to see his conceptual commonality with Lévi-Strauss. Recognizing that Lévi-Strauss's anthropology anticipated thinking on deconstruction and decentring would credit it with a discovery that Derrida wanted to claim as unique to his own approach.

Yet the theme of play, for both Lévi-Strauss and Derrida, acts like a kind of vector operating the limits of their respective thought. As Delruelle showed (1989), in Derrida's thought play becomes a block, a symptom of the refusal of any kind of horizon, which reveals the philosophical dead end to which Derrida is led; on the other hand, it does not show any logocentric naïvety in Lévi-Strauss. On the contrary, Lévi-Strauss' play metaphor points to his overcoming of the linguistic model, moving toward a structured model generative of open-ended meaning through which he has exerted a powerful influence. Across virtually all ethnographic texts and ranging over every part of the world, transformational narrative games still surface in unlikely texts far from their original source.

\section{The narrative of games}

The strategic importance of Lévi-Strauss's critique of ethnocentrism was to question the objectivity and universality of Western history. He challenged the notion of progress and relativized the achievements of Western science and technology from the point of view of societies that function as machines for the suppression of time and disorder at the level of history and social relations. In contrast to the historian and the philosopher, who were unable to transcend a particular and situated conceptual universe, the structural anthropologist aimed at a more detached and objective view on the range and nature of human experience.

Lévi-Strauss sought to transform the received Hegelian and Marxian narratives of the evolution of historical consciousness while remaining sensitive to the global contexts of cultural change. In place of the Hegelian division of peoples with and without history and the Marxian evolutionist categorization of infrastructural formations, he divided the world into hot and cold processes, scientific and 'savage' minds. Those Lévi-Straussian antinomies and his suspicion of history as both method and subject matter, together with his 'deconstruction' or 'dissolution' of a number of other archaic illusions, have structured much subsequent thought about post-colonial history and post-modernism.

For Lévi-Strauss, history consisted solely of method: 'even history which claims to be universal is still only a juxtaposition of a few local histories' (1962: 340 [257]). In this way, the structural anthropologist paved the way for post-modernism. From Lévi-Strauss' account of the tragic march of literate rationalism and his opposing of local histories to universal history, later theorists would draw the post-modern critique. Universal history and meta-narrative (grandes histoires) are made up of 'clouds of stories', Jean-François Lyotard was to say some years later (1979): 'they are a mass of billions of local histories (historiettes)'. Indeed, Lévi-Strauss' work on the 'savage' discourse he termed bricolage cleared the ground for Lyotard's influential analysis of narrative mastery, and the enthusiasm for an authentically primitive other shines through his privileging of local over master meta-narrative.

Lyotard can hardly be described as a Lévi-Straussian, nor has he shown much interest in thematizing orality and literacy, but as Klein (1995) points out, his popular coinages of the post-modern critique, 'master' and 'local' narratives, reinscribed the older, Lévi-Straussian antinomies of science and 'savagism', of statistical and mechanical models, cumulative and stationary history, hot and cold societies. The essence of the question of culture, the opposition between history and counter-history, history and culture, universal and local histories, literacy and orality, identity and multiplicity, order and disorder, symmetry and entropy, stability and change - all these boundaries between those with history and those deemed without any - had been carved out and deconstructed, indeed 'dissolved', long before the advent of post-modernism and post-structuralism.

Much more, like the theory of myth which is subjectively verified by his own experience of writing, Lévi-Strauss' symbolic production is merely a point in a network of cultural signification, a local expression of the whole system. After all, what Einstein did for natural science, in demonstrating the strict patterning of the structural relativity of the universe, Lévi-Strauss did for social science by revealing the rigorous patterning in the transformational structure of myths, conferring on them the same status of absolute objects. In each case, the analysis highlighted the mythic and relative character of those objective realities, to the extent that the universe and nature, like humans (including myth analysts and physicists), 'have simply demonstrated the resources of their combinatory systems, in the manner of some vast mythology, before collapsing in upon themselves and vanishing to the self-evidence of their own decay' (Lévi-Strauss 1971: 620-621 [694]).

Lévi-Strauss did not simply question and relativize categories of thought and modes of behaviour we normally take for granted, such as the category of self (which, according to some histories of human consciousness, has profoundly influenced the development of Western civilization); he effectively dissolved them. In what seems like an inverted parody of Sartre's existentialism, as Johnson (2003) notes, Lévi-Strauss takes his own singular 'lived experience' of the decentred self to be universalizable. We are all of us merely the passive sites of events, the interchangeable points of realization of virtual realities, echoing the Einsteinian universe governed by chance at an indeterminate time and place, where everything is ultimately a property of space and a position in space.

Significantly, the epigraph to Tristes tropiques is taken from De rerum natura, quoted in the original Latin, suggesting perhaps that the transience of human existence is an extension and modulation of physics. Atoms fall, draw together, combine and conglomerate to form the objects of the material world, which in their turn disintegrate and dissolve into the infinite flow of falling atoms. The nature of the universe is continual flux, and its general rule is entropy. The transience of the physical world is mirrored in the instability of human affairs, which are even more subject to change. This recognition of transience leads to an attitude of detachment and resignation, and it is this mood and message that seem to pervade both the heroic quest of Tristes tropiques and the high science of Mythologiques, which revealed the workings of The savage mind.

Lévi-Strauss always saw himself as working toward a science that could connect mind and the world, using his own formidable generalizing capacity to reduce empirical differences and to reveal the commonalities that he believed lay beneath the jumble of surface reality. Thus his materialist thrust was simply refocused on 'fundamental structures of the human mind', sparing him the accusations of both idealism and crude materialism. He could thus maintain his empirical interests and reject such criticisms. The empirical and analytical experience of structural procedures in anthropology, in any area that could become the subject of philosophical speculation, had the advantage of contributing to a 'regressive erosion' of all that had been taught by the philosophers (Lévi-Strauss 1971: 570[638]), 
Haverkamp, Anselm (ed.) 1995. Deconstruction is/in America. New York: New York University Press.

Johnson, Christopher. 2003.

Claude Lévi-Strauss:

The formative years. Cambridge: Cambridge University Press.

Klein, Kerwin L. 1995. In search of narrative mastery: Post-modernism and the people without history. History and Theory: Studies in the Philosophy of History, 34 (4): 275-298.

Lévi-Strauss, Claude 1962. La pensée sauvage. Paris: Plon. [Engl. transl. London: Weidenfeld \& Nicolson, 1966].

- 1964. Le cru et le cuit (Mythologiques I). Paris Plon. [Engl. transl. New York: Harper \& Row, 1969].

- 1971. L'homme nu (Mythologiques IV). Paris: Plon. [Engl. transl. New York: Harper \& Row, 1981].

— 1998. Retours en arrière. Les Temps Modernes, 53(598): 66-77.

Luhrmann, Tanya M. 1990. Our master, our brother: Lévi-Strauss's debt to Rousseau. Cultural Anthropology, 5(4): 396413.

Lyotard, Jean-François 1979. La condition postmoderne: Rapport sur le savoir. Paris: Minuit. [Engl. transl. Minneapolis: University of Minnesota Press, 1984].

Polier, Nicole and Roseberry, William 1989. Tristes tropes: Post-modern anthropologists encounter the other and discover themselves. Economy and Society, 18(2): 245-264.

Renaut, Alain 1992.

Naturalisme ou

humanisme? Discussion de Lévi-Strauss. Cahiers de Philosophie Politique et Juridique (Université de Caen), 22: 119-137.

Ricoeur, Paul 1969. Le conflit des interprétations: Essais d'herméneutique. Paris: Seuil.

Sangren, P. Steven 1988. Rhetoric and the authority of ethnography: Postmodernism and the social reproduction of texts. Current Anthropology, 29(3): 405-435.

Sartre, Jean-Paul 1960. Critique de la raison dialectique. Paris: Gallimard. [Engl. transl. London: NLB, 1976]

Spencer, Jonathan. 1989. Anthropology as a kind of writing. Man 24(1): 145-164. in such a way as to send them back to what Nietzsche had already termed their 'phantasmagorias'. It is ironic that these questions not only explain why he maintained his distance from post-structuralist thought; they also clarify how Lévi-Strauss, whose ambition was to discover a universal theory of mind, in fact at least partially inspired the modern turn toward deconstruction and subjectivity, inadvertently paving the way for contemporary post-modernism, a movement he deeply deplores.

A number of early critiques have already suggested that post-modernism in anthropology does not provide any new theoretical focus in the development of the field (Sangren 1988, Polier and Roseberry 1989, Spencer 1989). Despite its trappings of political and intellectual radicalism, postmodern anthropology is, in some of its assumptions, a depressingly reactionary endeavour. It may be perceived as a greater threat, with both traditional and critical concerns of the field gradually being dismantled in the name of a position that everybody is desperately seeking in the intellectual division of labour of the 'post-modern cultural condition'.
That is why the anthropologist who was once a hero now has more influence in the humanities than in his own field, which, he fears, has descended into internecine warfare. He now considers that anthropologists, for lack of an academic project, seek to occupy their time in philosophy, psychoanalysis or literature, 'running the risk of letting their discipline lose itself in a magma that, lacking a positive definition, is rather loosely glossed post-structuralism or post-modernism in the apophatic style of theologians' (Lévi-Strauss 1998: 76). In response to the new wave and to the 'loss of landmarks affecting post-modernist regression in anthropology', he has actually retreated from making any global claims and has distanced himself from the fray. Serene in his faith in the illusion of progress and the limits of human knowledge, he increasingly defines himself as a synthesist, the individual who brings order and coherence to the mass of data generated by fieldwork, the intellectual craftsman struggling to discover patterns in a recalcitrant world of dizzying uncertainty.

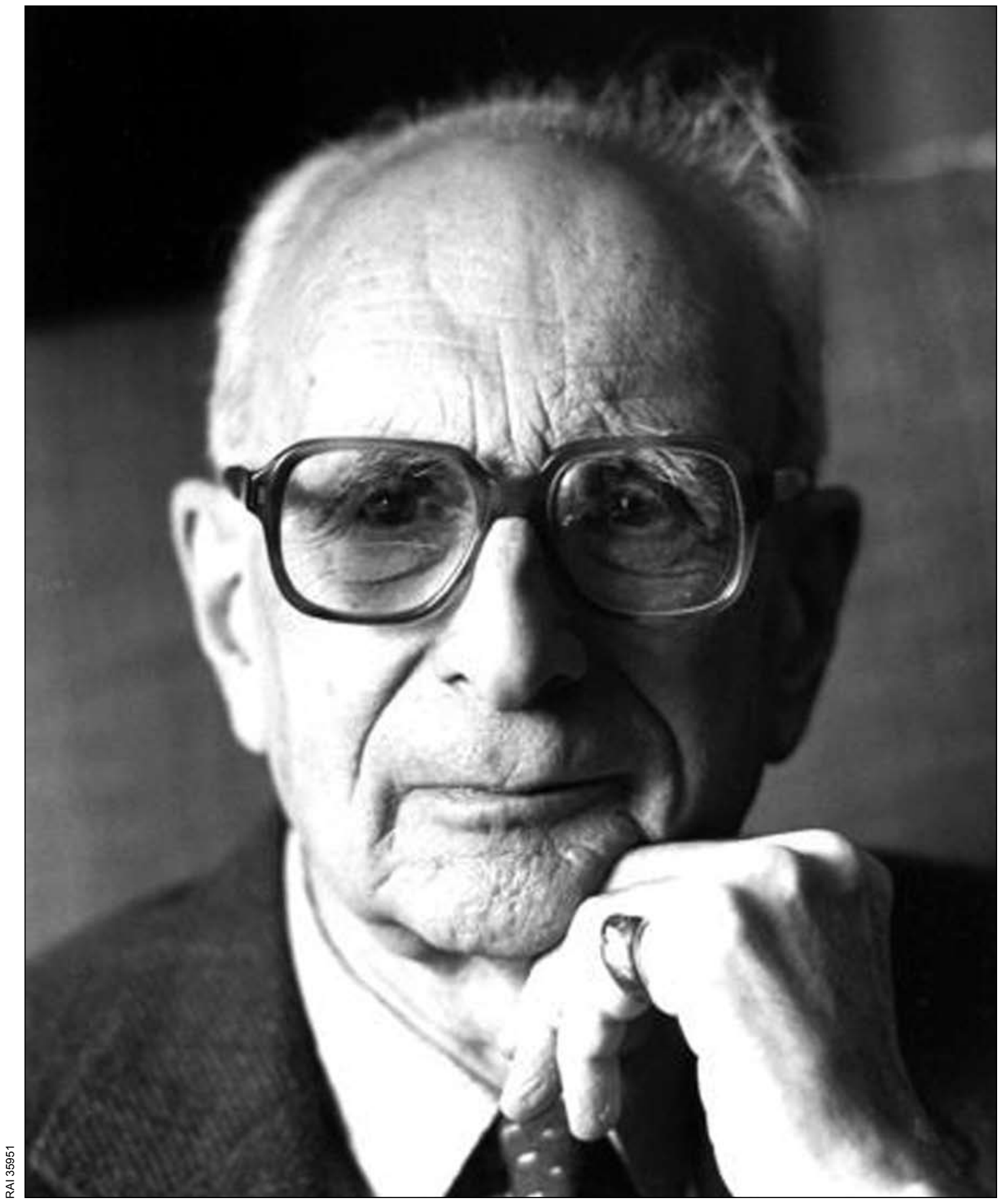

